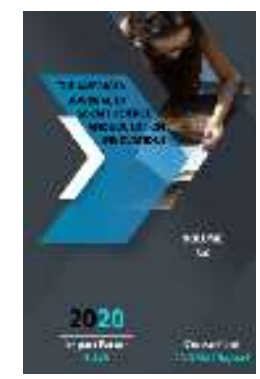

\title{
Conditions For The Formation Of Ming Romans
}

\author{
Samida Toshmukhammedovna Mustafaeva \\ Phd, Associate Professor, Department Of "Chinese Philology", Tashkent State University Of \\ Oriental Studies, Uzbekistan
}

Journal Website: http://usajournalshub.c om/index,php/tajssei

\section{ABSTRACT}

The Ming period is recognized as a period that introduced a new genre to Chinese literature, especially Chinese prose. During this period, novels from the masterpieces of Chinese literature saw the light of day. They are a valuable source for the study of Chinese literary language, as well as providing valuable information on the plot, historical facts, and the Darwin. In particular, the novel "Three Kingdoms", created in the Ming period, has a large volume and a plot rich in sharp turns, the events of the novel are based on the collapse of the Eastern Khanate, in general, various contradictions in public administration, political, military and foreign relations. The diversity in the author's depiction of contradictions and struggles, the uniqueness in the depiction of each event, demonstrates the writer's unparalleled artistic skill. In contrast to the "Three Kingdoms", the plot of "Water Margins" is based on the peasant uprisings and struggles; the play depicts the emergence, development and decline of the peasant uprising. The play praises a number of rebellious heroes, most of the protagonists of the work are extremely vivid, and their character is clearly described. The influence of the successful creation of the novels "Three Kingdoms" and "Water Margins" on the creation of historical and heroic novels of the next period is incomparable.

The first phase of the Ming period was a turning point in the history of literature. With the end of the Yuan Dynasty (元朝 Yuán cháo 1206-1368) and the beginning of the Ming Dynasty, no other significant works were created during this period, except for two major novels, the Three Kingdoms ( 《三国演 义》) and the River Basins (《水湤传》). It was not until 1465 that there was a renewal in drama and folk poetry.

\section{KEYWORDS}

“Three kingdoms", novel, heroic novels, historical prose, social and political situation, Water Margins, literary language, baihua, written speech, The Ming dynasty. 


\section{INTRODUCTION}

The Ming Dynasty (1368-1487) was a turning point in the history of Chinese statehood in various fields such as political, economic, and social and international relations. During the Yuan Dynasty, the country, which was on the brink of collapse in all respects, managed to restore and strengthen its position under the Ming dynasty, both inside and outside the country.

\section{THE MAIN FINDINGS AND RESULTS}

By the middle of the 14th century, the economy of the Yuan Empire was in dire straits. The Yuan government's policies disrupted urban life and North China's agriculture. The whole country was in a very sad state. The Yuan government was making new decisions to ban citizens from keeping weapons at home in order to prevent sudden popular uprisings. All this indicated that the Yuan administration was on the verge of collapse [1, p. 127].

Despite the Yuan government tightening control, peasant uprisings began to erupt in all provinces, backed by the townspeople and the people of the South. In such a difficult situation, the people's dissatisfaction with the government, their grief was reflected in folk songs, fairy tales and legends. Legends about invincible heroes, famous commanders, heroes, and just people were especially popular among the people. Stage performances on this theme were staged and works of art were created [1, p. 128]. It was in this situation that the novel The Three Kingdoms came into being.

Chinese scholars divide the literature of the Ming period into two periods: 前期 qianqi (first period) and 后期 houqi (later period). Due to the fact that the first period was a period of economic, social and political recovery in the country, the development of literature was relatively slow, during which two significant works 《三国演义》“Three Kingdoms” and 《水浒传》“Water Margins” were created. The writing of these two novels dates back to the end of the Yuan Dynasty and the beginning of the Ming Dynasty. According to reports, the peasant uprising that erupted in the last years of the Yuan dynasty's rule as a result of disputes between social classes and national conflicts spread widely and ignited the flames of war in almost all regions of the country.

Whether this situation was direct or indirect, it did not go unnoticed by intellectuals, especially writers. Luo Guanjung (罗贯中), author of the novel Three Kingdoms, and Shi Nay'an（施耐 庵）, author of The River Rivers, also took part in similar uprisings. Therefore, the authors managed to compile and polish the legends related to the construction of the three kingdoms and rivers, which have been popular among the people for centuries, and create two great masterpieces mentioned above [2].

The Three Kingdoms is the first historical novel to be written in (《三国演义》) Chinese literatures. The large volume and complex plot of the work allowed covering in detail the military, political, diplomatic and other conflicts between the political groups formed by the feudal lords of the last years of the Eastern Khanate and the three dynasties [2]. The most important difference of this novel 
from other novels is that the main narrative of the novel consists of historical events. The fate of the heroes in the novel, in a sense, rises to a secondary level [3, p. 198].

\section{“Water Margins" is a novel about (《水汻传》}

) peasant uprisings, which skillfully illuminates the process of emergence, aggravation and suppression of the uprising by means of art. Thousands of heroes are praised in the play, they are embodied alive and the character of the heroes is clearly revealed. "Water Margins" is the first example of a heroic novel in Chinese literature. Unlike the novel "Three Kingdoms", the protagonists are woven characters. The novel is imbued with Confucian ideas. The presence of plots on Chinese national ideology and values also defines the unique place of "Water Margins" in Chinese literature [3, p. 199].

The period from the reign of Emperor Tai Tzu (1368) to the reign of Yin Zun (1464) is considered to be the first stage of the literature of the Ming period. This period was a period of economic recovery, development of production, stabilization of political domination and strengthening of borders for the Ming dynasty. Emperor Tai Tsu, Zhu Yuanchjan, along with carrying out a number of social and economic reforms, also attached great importance to the development of science. In the process of increasing the number of intellectuals in the ranks of palace officials and appointing them to positions, the eight basic works introduced (八股文 baguwen) examination systems. He demanded that intellectuals read "four books" and "five holy books". In this way, the connection to ancient philosophy (mainly Confucian ideas) led to limitations in the literature. It is no exaggeration to say that the ideological limitations of the creators, the political pressure cast a serious shadow on the art of the first phase of the Ming period.

Emperor Tai Tzu severely punished any crimes such as treason, abuse of office, bribery. There have been several repressions in the country. The emperor justified such a harsh policy in his "great speeches". Such works of his were in the form of advice to good and bad ministers, public administration, his successors [4, pp. 371-375]. The emperor was a supporter of Confucian ideas and in 1370 re-established the examination system in his appointments [5]. He never forgot his origins and brutally punished the peasants, the common people who protected, appropriated or plundered their property. Twenty thousand people were executed in the repressions [4]. As a result of Tai Tzu's tough policy, peace was stabilized in the country. In 1369, he "named" the spirits of all the walls and walls of the shrine and ensured that they were constantly sacrificed. These efforts to make cities prosperous have paid off, and the economic situation in the country has begun to improve. The military achievements of the expedition to Tibet, the strengthening of the position in Manchuria, and the liberation of Yunnan and Sichuan provinces from the Mongols. After the death of Tai Tsu in 1398, Hui-di took the throne and called his time the Chen-wen period. He was a very gentle, bookloving man, and began to gather around him representatives of Confucianism. After the decision to reduce the powers given to his uncles by his father, the country began to be beaten by civilians led by Prince Yan. The culmination of the three-year bloody conflict took place in 1402, when the traitor opened the gates of Nanjing to the rebels. The imperial palace is set on fire. In 1403, Prince Yan 
declared himself emperor. He took the name Chen-tzu and declared his reign as the era of Yun-le (eternal joy). He was more interested in the military.

Nevertheless, he appointed only those who successfully passed the exam to public office. According to the imperial decree, scientists have compiled a "philosophical collection of human nature" containing classical works and commentaries on them. He also funded the Yun-le Literary Treasure, a collection of more than 2,000 scholars. This collection of twentytwo thousand chapters includes classical literature, history, traditions, laws, military campaigns, medicine, zoology, botany, legends, and drama [4, pp. 375-377]. The emperor considered it his main goal to increase Chinese influence in the North, in the center of Asia. He made good use of diplomatic methods by sending ambassadors to neighboring countries. This circle included mainly Korea, sometimes Japan, but the new shogun of the Japanese in 1417 stopped foreign relations, saying that the Japanese gods were not to have any relations with foreigners. However, the military action will not stop [4, p. 377]. In the Ming period, the main threat from the North was the empire of Timur (Tamerlane). Two ambassadors sent to Timur by emperors Tai Tsu and Chen Tszu were also executed. In 1404, Timur, who was about to invade China with an army of 200,000, died. However, this does not ensure the security of the Northern borders [4]. The emperor himself draws troops and fights to defend the northern borders. But border security is not fully guaranteed. The Emperor also managed to subdue it by marching to Annam (northern part of presentday Vietnam), but the Ming Empire gave up the area as the uprisings there continued unabated. Emperor Chen Tszu's contribution to the navy was enormous. China carried out naval expeditions long before Europe during the reign of Emperor Chen Tszu. The benefits for the country were significant. The emperor wanted to move the capital from Nanjing to Beijing. By his order, the city was almost completely reconstructed. Most of the palaces and architectural monuments built at that time have survived to this day. Urban planning took 15 years and employed 100,000 workers. The construction of a large canal allowed for uninterrupted supply of food from the south.

However, the emperor did not live long in this city, which he rebuilt, and died in 1424 [4, pp. 378-379]. The throne is taken by his eldest son, Jen-tsun, but he also dies a year after his father's death due to health problems. Then begins the reign of Xuanzong, the heir to the throne Jen-tsung. An uprising erupts due to his uncle's dissatisfaction with Xuanzong's accession to the throne. But the revolt was quickly suppressed and his uncle and the 2,200 people associated with him were punished. After this incident, peace reigned in the country. Xuanzun, like his ancestors, was brought up according to Confucian ideas. He also involved scientists from the Hanlin Academy in government administration [4, p. 380]. He made history as a righteous emperor. It was during the reign of Emperor Xuanzong that peace was ensured inside and outside the country. Foreign relations, in particular trade relations with Korea and Japan, by sea, and relations with Arabia and Africa were strengthened, and the struggles in Annam were finally put to an end. Emperor Xuanzong, who died in 1435, was recognized by historians as a perfect monk for Confucian ideas [4, p. 380]. 


\section{CONCLUSION}

Such a complex political, economic, and ideological situation in the Chinese country of Ming did not go unnoticed in the works created during this period. Therefore, the novel "Three Kingdoms" is important for raising the morale of the people, strengthening the political ideology by praising the heroes of history, while the novel "Water Marginss" is based on the story of the construction of the Great Canal.

\section{REFERENCES}

1. History of China. - Moscow. Main edition of oriental literature. 1974. - P.127.

2. www.cnki.net

3. Ziyamuhammedov J., Ochilov O., Nasimova S. (2016) Chinese literature. - Tashkent. p.198.

4. Kruger R. (2008) China: the history of the country. - Moscow. - pp. 371-375.

5. Note: During the reign of Tai Tsu, the examination system included classical works, oratory, political observation, archery, horseback riding, calligraphy, arithmetic and legal documents. However, after some time, the system was abolished again, and appointments were made on the basis of recommendations.

6. Essays on Style and Language. Linguistic and Critical Approaches to Literary Style. L.: 1966. 